\title{
Orbital Exenterations: Our experience at Ankara Oncology Research And Training Hospital
}

\author{
Rahmi DUMAN ${ }^{1}$, Mehmet BALCI ${ }^{1}$, Reşat DUMAN ${ }^{2}$, Sibel OZDOGAN ${ }^{1}$ \\ ' Ankara Oncology Hospital, Department of Ophthalmology, Ankara \\ ${ }^{2}$ Emirdağ Hospital, Department of Ophthalmology, Afyon, TURKEY
}

\begin{abstract}
The aim of this study is to review our 5 year experience with orbital exenterations and to evaluate the demographic and clinical features of patients, indications and outcomes. Between January 2008 and December 2012, 16 patients who underwent orbital exenteration were included in the study. Most of the lesions originated from eyelid $(n=14)$ and remaining 2 lesions originated from orbit. Histopathological examination of the lesions were consistent with basal cell carcinoma $(n=7)$, squamous cell carcinoma $(n=5)$, sebaceous carcinoma $(n=2)$, choroidal melanoma $(n=1)$ and adenoid cystic carcinoma $(n=1)$. Secondary orbital tumours are the major indication for orbital exenteration. Aggressive removal of primary tumours can reduce the frequency of this disfiguring procedure.
\end{abstract}

Keywords: Orbital exenteration, Orbital tumour, Squamous cell carcinoma, Basal cell carcinoma, Eyelid sebaceous carcinoma

\section{ÖZET}

\section{Orbital Ekzenterasyonlar: Ankara Onkoloji Araştırma ve Eğitim Hastanesindeki Deneyimlerimiz}

Bu çalışmanın amacı orbital ekzenterasyonlarla ilgili beş yıllık deneyimlerimlerimizi gözden geçirmek, hastaların demografik ve klinik özelliklerini, endikasyonlarını ve sonuçlarını değerlendirmektir. Ocak 2008 ile Arallk 2012 arasında, orbital ekzenterasyon yapılan 16 hasta çalışmaya alındı. Lezyonların çoğu göz kapağından kaynaklanmakta, geriye kalan 2 lezyon ise orbitadan (\% 12.5) kaynaklanmakta idi. Lezyonların histopatolojik incelemesi bazal hücreli karsinom $(n=7)$, skuamöz hücreli karsinom $(n=5)$, sebase karsinom $(n=$ 25), koroidal melanom $(n=1)$ ve adenoid kistik karsinom $(n=1)$ ile uyumlu idi. Ekzenterasyonların en önemli endikasyonu sekonder orbita tümörleri idi. Primer tümörlerin agresif tedavisi kötü görünüme sebep olan bu prosedür sıklığını azaltabilir.

Anahtar Kelimeler: Orbital ekzenterasyon, Orbital tümör, Yassı hücreli karsinom, Bazal hücreli karsinom, Göz kapağının sebase bez karsinomu 


\section{INTRODUCTION}

Orbital exenteration is a disfiguring procedure most commonly performed for locally advanced or recurrent periorbital malignancies. This procedure typically involves complete removal of the eyeball, the retrobulbar orbital soft tissues and most or all of the eyelids. ${ }^{1-3}$ This psychologically and anatomically disfiguring procedure is usually performed to treat potentially life threatening malignancies or progressive conditions unresponsive to other treatments.

Yeatts ${ }^{1}$ divided exenteration into 2 categories ${ }^{1}$ :

(a) Total exenteration (TE) which involves the removal of the entire orbital content with or without sacrifice of the eyelid skin and

(b) Subtotal exenteration (STE) involving partial removal of orbital tissues with sacrifice of the eye.

Extended exenteration (ETE) is performed for tumor-free surgical margins and it may include the adjacent orbital bone walls and paranasal sinus tissues.

The aim of this study is to review our 5 year experience with orbital exenteration at Ankara Oncology Research and Training Hospital, Department of Ophthalmology.

\section{PATIENTS AND METHODS}

Medical records of all patients who underwent orbital exenteration were reviewed retrospectively from January 2008 to December 2012. Data about the demographic profile, clinical presentation, primary lesion site, histopathologic diagnosis, indication leading to exenteration, previous treatments elsewhere and postoperative complications were recorded. Surgical technique, adjunctive postoperative treatments (further surgery, radiotherapy, chemotherapy), intraoperative and postoperative complications and recurrences were also noted. The patients were informed about their disease and a written consent was obtained. All exenterations were performed under general anaesthesia.

\section{RESULTS}

A total of 16 exenteration were included in the study. $68.7 \%$ of the patients $(n=11)$ were male and median age was 63.5 years (range: 50-79 years).
The male/female ratio was 2.2. All exenterations were performed for life threatening malignant neoplasms and secondary orbital tumours were the major indication $(n=14 ; 87.5 \%)$. Primary orbital tumours $(\mathrm{n}=1 ; 6.2 \%)$ and lacrimal gland tumours $(n=1,6.2 \%)$ were the other indications.

The eyelid was the most common site of tumor origin, accounting for $14(87.5 \%)$ patients. Of the 16 orbital lesions $12(75 \%)$ required TE and remaining $4(25 \%)$ had ETE. Paranasal sinus resection was also performed in four patients (25\%) with sinus involvement. Histopathological examination of the lesions revealed basal cell carcinoma (BCC) $(n=7$; $43.75 \%)$, squamous cell carcinoma (SCC) $(n=5$; $31.25 \%)$, eyelid sebaceous carcinoma (ESC) $(n=2$; $12.5 \%)$, choroidal malignant melanoma (CMM) $(\mathrm{n}=1 ; 6.2 \%)$ and adenoid cystic carcinoma (ACC) $(\mathrm{n}=1 ; 6.2 \%)$. Patient demographics, tumour origins, performed surgery types and histopathological diagnoses were shown in Table 1.

A majority of patients $(n=12 ; 75 \%)$ in this study had eyelid BCC $(n=7 ; 43.75 \%)$ and eyelid SCC $(\mathrm{n}=5 ; 31.25 \%)$. In $\mathrm{BCC}$ group, the median disease duration was 78 months (range: 12-156 months). All patients had recurrent lesions and had previously undergone an operation and/or radiotherapy. 2 of total 7 patients with eyelid BCC had initial lesions in the medial or lateral canthal area. Combined with exenteration, bone resection in 2 patients, paranasal sinusectomy in 2 patients were performed. Scleral invasion was detected in 1 patient. Histopathological subtypes of BCC were; infiltrative $(n=5)$ and nodular $(n=2)$. Perineural invasion (PNI) was detected in 1 patient. All patients received postoperative radiation therapy after exenteration.

In SCC group, median disease duration was 25 months (range: 9-54 months). All of the lesions were recurrent and previously treated elsewhere. Four of total 5 lesions originated from the lower eyelid and remaining 1 lesion from upper eyelid. Combined with exenteration, bone resection in 1 patient, paranasal sinusectomy in 1 patient were performed. Scleral invasion was detected in 1 patient. Three lesions were well differentiated SCC, and remaining 2 were poorly differentiated SCC. In 3 patients, PNI was detected. All patients received postoperative radiation therapy after exenteration. 
lasms. Bartley et al. ${ }^{2}$ reported that 100 of their 102 $(98 \%)$ exenterated cases were malignant tumours. Levin et al. ${ }^{3}$ (94\%) and Mohr and Esser $^{4}$ (96\%) reported similar results. In our study, all of the exenterations were performed for orbital and periorbital malignant neoplasms. The fact that our hospital is a refarral center for oncological cases may explain why all exenterations were performed for neoplasms.

In the previous studies of exenteration, the rates of $\mathrm{BCC}$ have been documented to range from $8 \%$ to $44 \%{ }^{5}$ Bartley et al. ${ }^{2}$ reported that eyelid BCC was the most frequent neoplasm that made up $21 \%$ of all their exenterations. In other large series; Rathbun et al.6, Rahman et al. ${ }^{7}$ Mohr and Esser4 and Levin and Dutton ${ }^{3}$ reported BCC rates as 29\%, $44 \%, 8 \%$ and $8 \%$ respectively. Various SCC rates were reported in the previous studies. In a study with 429 cases of orbital exenteration, SCC was the most frequent indication for orbital exenteration, accounting for over $30 \%$ of all cases. ${ }^{8}$ Rathbun et al.6 reported $12.5 \%$ SCC rate. In an other study with 25 cases, SCC rate was reported as $76 \% .^{9}$ In our study eyelid BCC (43.75\%) were the most common neoplasms leading to exenteration.

These variations of indications for exenteration in different series can be explained by different ethnic groups of patients, differences in the prevalance of ophthalmic malignancies and different early diagnostic and treatment modalities in different centers.

In our study exenteration was performed mostly ( $87 \%$ ) because of the secondary orbital spread of malignant neoplasms. Our all BCC and SCC patients experienced failed previous treatments and had recurrent lesions. Some factors such as inadequate previous treatments and follow up, long durations until diagnosis and neglect of the lesions by the patients until the disturbing symptoms occur can be an explanation for this situation. In previous studi$\mathrm{es}^{7,10}$ late presentation, inadequate initial surgery and insufficient follow-up are reported as the main risk factors for spread of BCC to the orbit. So secondary orbital spread of primary lesions and exenterations can be avoided if malignancies are diagnosed and treated at an earlier phase and patients are followed up closer.

In our study, the median duration of disease from the onset of primary lesion in BCC and SCC groups was 78 months and 25 months respectively. In previous studies, eyelid SCC was reported to be more aggresive than BCC exhibiting orbital spread at an earlier stage. ${ }^{12,13}$ Longer duration in BCC group in our study can also be explained by late presentation of cases and slow growing feature of the disease and more aggressive course of SCC.

In previous studies recurrence rates of $7 \%$ to $10 \%$ have been reported in cases of locally invasive tumors (such as BCC and SCC) when all the involved tissue was removed and clear margins were seen on histopathology., ${ }^{6,13-14}$ In our study local recurrence rate was $18.7 \%$ and recurrences were observed within a median of 2.3 years. We suggest that the first three years are the most important period for follow-up of local recurrences. Various ESC rates were reported in the previous studies. In a study with 38 cases of orbital exenteration ESC was $13.5 \%$ of all cases ${ }^{13}$ and similarly Song et al. ${ }^{15}$ reported $13 \%$ ESC rate. In our study ESC was the indication of exenteration in $2(12.5 \%)$ cases.

In the literature sino-orbital fistula is the most common complication of exenteration. It is more common in cases treated with post-operative radiotherapy but it may also ocur after a damage to the meadial wall or floor of the orbit. It may be left to heal or repaired with muscle flap or skin graft. ${ }^{16}$ In our study postoperative complications were: sino-orbital fistula and late postoperative fungal infection of orbital cavity in 1 patient with ACC. Fungal infection was treated with antifungal therapy without any complication.

In conclusion, orbital exenteration is mostly performed in curing locally aggressive eyelid tumors such as BCC and SCC. Secondary orbital spread of these lesions and need for exenterations can be avoided if these malignancies are diagnosed and treated at an earlier stage and if patients are followed up closely.

\section{REFERENCES}

1. Yeatts RP. The esthetics of orbital exenteration. Am J Ophthalmol 139: 152-155, 2005.

2. Bartley BG, Garrity JA, Waller RR, et al. Orbital exenteration at the Mayo Clinic, 1967-1986. Ophthalmology 96: 468-473, 1989.

3. Levin PS, Ellis DS, Stewart WB, et al. Orbital exenterations: the reconstructive ladder. Ophthal Plast Reconstr Surg 7: 84-91, 1991. 
4. Mohr C, Esser J. Orbital exenteration: surgical and reconstructive strategies. Graefes Arch Clin Exp Ophthalmol 235:288-295, 1997.

5. Soysal HG. Orbital exenteration: A 10-year experience of a general oncology hospital. Orbit 29: 135-139, 2010.

6. Rathbun JE, Beard C, Quickert MH. Evaluation of 48 cases of orbital exenteration. Am J Ophthalmol 72: 191-199, 1971.

7. Rahman I, Cook AE, Leatherbarrow B. Orbital exenteration: a 13 year Manchester experience. Br J Ophthalmol 89: 1335-1340, 2005.

8. Günalp I, Gündüz K, Dürük K. Orbital exenteration: a rewiev of 429 cases. Int Ophthalmol 19: 177-184, 1996.

9. Ackuaku-Dogbe E. Review of orbital exenterations in korle-bu teaching hospital. Ghana Med J 45: 45-49, 2011.

10. Mahashweri R. Review of orbital exenteration from an eye care centre in Western India. Orbit 29: 35-38, 2010.

11. McKelvie PA, Daniell M, McNab A, et al. Squamous cell carcinoma of the conjunctiva: a series of 26 cases. Br J Ophthalmol 86: 168-173, 2002.

12. Tunc M, Char DH, Crawford B, et al. Intraepithelial and invasive squamous cell carcinoma of the conjunctiva: analysis of 60 cases. $\mathrm{Br} \mathrm{J}$ Ophthalmol 83: 98-103, 1999.

13. Nemet $\mathrm{A} Y$, Martin $\mathrm{P}$, Benger $\mathrm{R}$, et al. Orbital Exenteration: A 15-Year Study of 38 Cases. Ophthal Plast Reconstr Surg 23: 468-472, 2007.
14. Ben Simon GJ, Schwarcz RM, Douglas R, et al. Orbital exenteration: one size does not fit all. Am J Ophthalmol 139: 11-17, 2005.

15. Song A, Carter KD, Syed NA, et al. Sebaceous carcinoma of the ocular adnexa: clinical presentation, histopathology, and outcomes. Ophthl Plast Surg 24: 194-200, 2008.

16. Perman Kl, Baylis HI. Evisceration, enucleation and exenteration. Otolaryngol Clin North Am 21: 171-182, 1988.

\section{Correspondence}

Dr. Rahmi DUMAN

Çamlitepe Mah, Kıbrıs Caddesi

No: 9 / 4, Çankaya, ANKARA / TURKEY

Tel: (+90.555) 2473500

Fax: (+90.312) 3340352

e-mail: drrahmi42@yahoo.com 